\title{
Biomass Char Steam Gasification in Fluidized Reactor Using Nuclear Heat
}

\author{
Abdelhamid Belghit*, Ervin David Gordillo \\ University of La Rochelle, LaSIE, Laboratory of Engineering Science for Environment, La Rochelle, France \\ Email: *abelghit@univ-lr.fr
}

How to cite this paper: Belghit, A. and Gordillo, E.D. (2020) Biomass Char Steam Gasification in Fluidized Reactor Using Nuclear Heat. Open Access Library Journal, 7: e6155.

https://doi.org/10.4236/oalib.1106155

Received: February 11, 2020

Accepted: March 22, 2020

Published: March 25, 2020

Copyright $\odot 2020$ by author(s) and Open Access Library Inc.

This work is licensed under the Creative Commons Attribution International License (CC BY 4.0).

http://creativecommons.org/licenses/by/4.0/

(c) (i) Open Access

\begin{abstract}
The energy resources diversification has been increased with the energy crisis, in particular, the renewable energies and optimal management have become essential in the context of sustainable development. The conventional auto-thermal gasification processes burn part of the carbonaceous compound in order to supply the energy necessary to enhance gasification reactions. This energy could be provided as well by a nuclear reactor of IV generation. The nuclear heat is transferred from the VHTR to a He stream, which is mixed with the steam before entering the reactor. The syngas produced in this process has a high quality which is applicable for Fischer-Tropsch processor for power generation in fuel cells. The present work aims to develop a model for char steam gasification in a fluidized bed, with nuclear heat as the source of energy for the gasification reactions. The results of the model are compared with the data reported in the literature.
\end{abstract}

\section{Subject Areas}

Developmental Biology, Ecology, Environmental Sciences,

Thermal Sciences

\section{Keywords}

Biomass, Steam Gasification, Hydrogen Production, High Temperature, Fluidized Bed, Nuclear Reactors

\section{Introduction}

Throughout the history of humanity, energy has been the basis of the human technological development. The change of energy sources was mainly due to the change in mankind's perception of the safety and comfort. Initially, this perception was targeted toward individuality and freedom of personal mobility. How- 
ever, with the technological advances in astronomy, the man realized that life as we know it, is only possible on this planet, and at the same time, its resources are limited. These technological advances created a strong environmental awareness, we are still seeking technological development but the care for our resources of life is now included.

Hydrogen economy appears to be the best sustainable solution for the actual energy issues, including the depletion of fossil fuels and the vast amount of $\mathrm{CO}_{2}$ in the atmosphere causing global warming. The advantage of using hydrogen as an energy source is that water is the only combustion product [1].

Although hydrogen is a secondary energy source (it is not easily found in nature), some authors have described it as a clean energy source, its molecule is the simplest and the only product of its combustion is steam, therefore, zero carbon dioxide emissions are made. At the same time, with advances in fuel cells, hydrogen can be considered as stored electric energy.

Biomass is the most frequently used biofuel in the world [2] because of its neutral $\mathrm{CO}_{2}$ cycle and its high potential for hydrogen production [3]. Additionally, the low sulfur content and the high volatile matter in the biomass increase the advantages of the biomass gasification process. The latter is conducted in a steam-only atmosphere in order to produce a maximum of hydrogen with the biomass char as the carbon source. Moreover, only-steam gasification has the advantages of efficient tar reduction and higher char conversion [4] [5].

Given that the gasification process demands energy [6], through history, it has been designed to create an auto energy (auto-thermal) provider process. The first attempts were concentrated in the reactors design with combustion inside the gasifier, in this way, the combustion gases arise the temperature and the gasification reactions are enhanced. Nowadays, a large amount of the existing industry, pilot or laboratory scale gasifiers design is based on the experimental optimization of older models. As a consequence combustion is conducted in a great number of them.

Combustion inside the reactor is not desirable, the $\mathrm{CO}_{2}$ and nitrogen (when air is used) concentrations are increased and consequently hydrogen concentration is reduced. To solve this problem, some authors propose a dual system [3] [7] [8] in which the gasification products do not mix with those from the combustion, thus the hydrogen will not be diluted by nitrogen and other undesirable gases. This kind of reactors, in which the energy source is placed outside the gasifier main body, is known as allo-thermal. The main disadvantage is that part of the feedstock is used for non-gasification purposes, which reduces de process efficiency.

The aim to develop reactors with no combustion conducted has attracted the attention of the engineers responsible for the gasifiers design. The development in the nuclear (e.g. [6] [9] [10]) and solar or concentrated radiative energy (e.g. [12]-[18]) technologies for gasification in the recent years, made possible the design of several gasifiers, enhancing the hydrogen production and reducing the 
carbon dioxide yield, as well as, the process efficiency is increased as all carbon source is used only for gasification.

Depending on the energy source, the gases or the solids can be the hot phase inside the reactor. This is the phase that provides the energy to enhance the gasification reactions. For example, in auto-thermal gasifiers, the combustion gases are the hot phase. On the contrary, the gases are the cold phase in concentrated solar radiation or with external heating resistances gasifiers (allo-thermal processes).

The fluidized bed reactor seems to be the best solution for the gasifiers design. The most common gasifiers recently proposed [10] [11] [19]-[34] are fluidized bed reactors, because of their homogenous temperatures, high gas velocities which ensure a high mass and heat transfer, besides, the ideal gas-solids interactions for heterogeneous reactions enhancement. Nevertheless, depending on the energy source, if it is an auto-thermal or allo-thermal gasification, the hot phase (solids or gases), the ratio between phases and orientation of streams, a gasifier may be designed in a very different way compared to another with similar dimensions, especially if the gasifier is designed to optimize hydrogen production.

Currently, based on the parameters mentioned above, no items or articles are available in the literature with basic rules that help the engineer in the decisions for a good gasifier design.

This paper aims to present an alternative different than the conventional methods, i.e. fluidized bed with nuclear heat (Figure 1).

\section{Fluidized Bed Reactor}

The fluidized beds are complex systems in which the hydrodynamics are highly influential; therefore, the hydrodynamics are treated simultaneously with the gasification process.

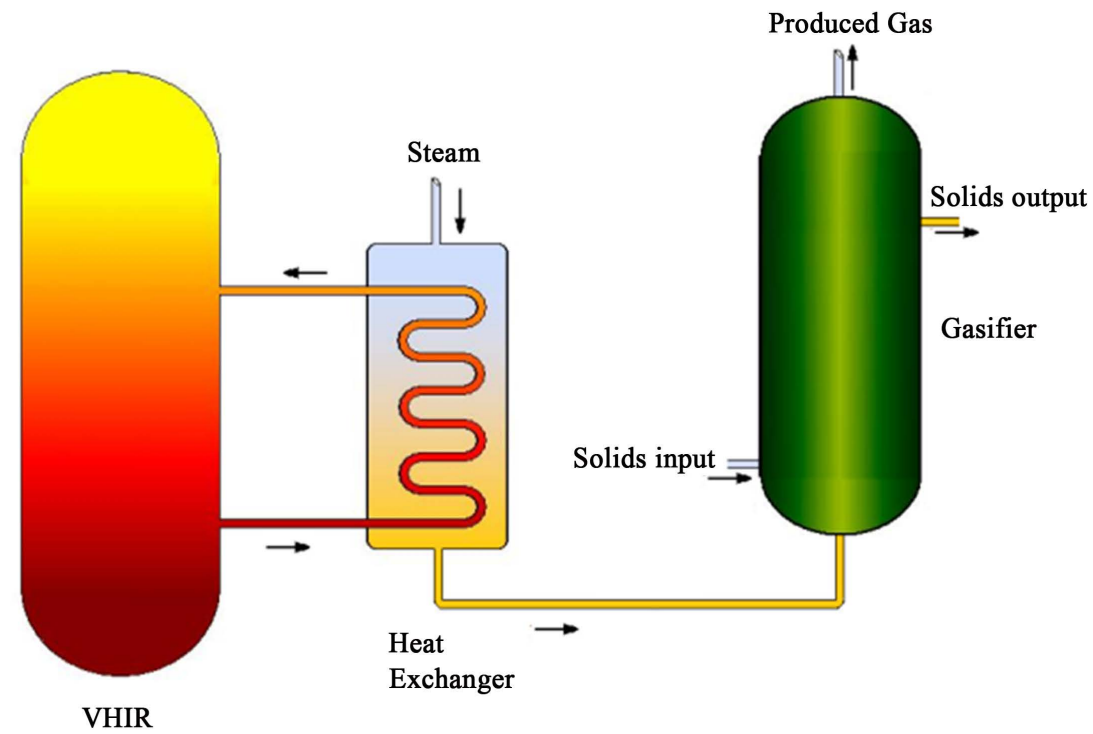

Figure 1. Hydrogen production with nuclear energy (VHTR plant with a bubbling fluidized bed gasifier) [10] [11]. 
In the model development, a "complete" gasification is presumed, which means that only $\mathrm{CH}_{4}, \mathrm{CO}, \mathrm{CO}_{2}$ and $\mathrm{H}_{2}$ are the gases produced during the whole process.

The nuclear heat as the source of energy has been described in detail elsewhere [6] [9].

\section{Reactor Description}

The two-phase theory of fluidization is implemented. Therefore, the emulsion and the bubble phases are separated and the mass and heat transfer occurs only between the bubbles and the emulsion and the emulsion and the solids [9] [23] [35] as shown in Figure 2.

The bubble diameter grows in relation to the reactor height. For bubbles in the same level in the reactor, the diameter is uniform, this is known as effective bubble size [36].

The following assumptions are made regarding the reactor operation:

- No inert gas is used in the gasification process;

- Ideal behavior of gases is considered;

- The bubbles are free of solids;

- The system parameters change only in the $Z$ direction (see Figure 3).

The reactor simulation uses the reactions shown in Table 1.

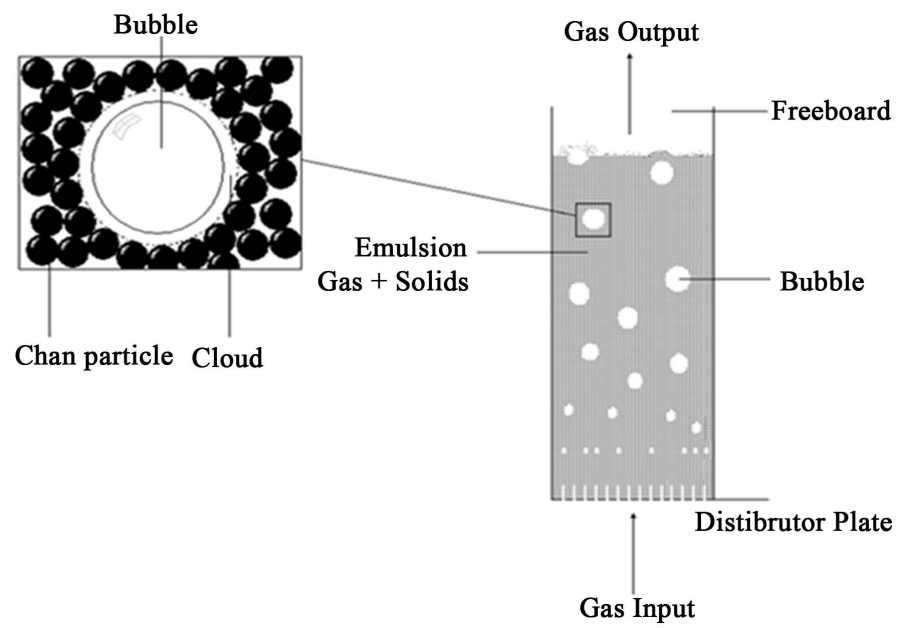

Figure 2. The bubbling fluidized bed gasifier in detail [10].

Table 1. Considered chemical reactions.

\begin{tabular}{ccccc}
\hline $\mathrm{R} \mathrm{n}^{\circ}$ & Name & Chemical reaction & $\begin{array}{c}\Delta H_{298 \mathrm{~K}}^{\circ} \\
(\mathrm{kJ} / \mathrm{mol})\end{array}$ & $\begin{array}{c}\Delta G_{298 \mathrm{~K}}^{\circ} \\
(\mathrm{kJ} / \mathrm{mol})\end{array}$ \\
\hline $\mathrm{R} 1$ & Water-gas shift reaction & $\mathrm{CO}+\mathrm{H}_{2} \mathrm{O} \leftrightarrow \mathrm{CO}_{2}+\mathrm{H}_{2}$ & -41.1 & -28.5 \\
$\mathrm{R} 2$ & Water-gas (primary) reaction & $\mathrm{H}_{2} \mathrm{O}+\mathrm{C} \leftrightarrow \mathrm{H}_{2}+\mathrm{CO}$ & 131.3 & 91.2 \\
$\mathrm{R} 3$ & Methanation reaction & $\mathrm{C}+2 \mathrm{H}_{2} \leftrightarrow \mathrm{CH}_{4}$ & -74.8 & -50.8 \\
$\mathrm{R} 4$ & Boudouard reaction & $\mathrm{CO}_{2}+\mathrm{C} \leftrightarrow 2 \mathrm{CO}$ & 172.8 & 119.8
\end{tabular}




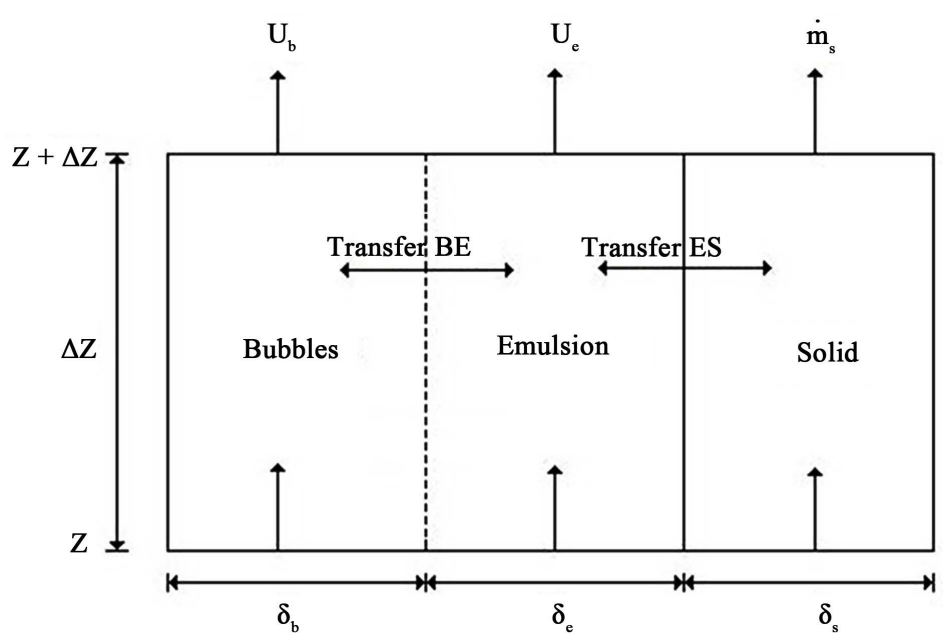

Figure 3. Volume control in the reactor [10].

\section{Gasifier Equations}

Figure 3 shows a volume control $\left(A_{R} \Delta Z\right)$ fixed in the fluidized bed.

- Heat balance for the solids:

$$
\begin{aligned}
\frac{\partial}{\partial t}\left(\delta_{s} \rho_{s} C p_{s} T_{s}\right)= & \dot{m}_{e} C p_{s} T_{s}-\dot{m}_{s} C p_{s} T_{s}+\frac{1}{A_{R}} \frac{\mathrm{d} A_{s}}{\mathrm{~d} Z} h_{s e}\left(T_{e}-T_{s}\right) \\
& -\frac{1}{A_{R}} \frac{\mathrm{d} A_{s}}{\mathrm{~d} Z} \sum_{j=2}^{4} r_{j} \Delta H_{r, j}+\frac{\partial Q_{r}}{\partial Z}
\end{aligned}
$$

where $Q_{r}$ is the radiative flux density, which is given by the approximation [37]: $Q_{r}(Z)=-\frac{16 \sigma T_{s}^{3}}{3 K} \frac{\partial T_{s}}{\partial Z}$.

- Heat balance for the $i$ th gas:

o In the bubbles

$$
\begin{aligned}
& \sum_{i=1}^{5} \frac{\partial}{\partial t}\left(\delta_{b} C_{i b} C p_{i}\left(T_{b}\right) T_{b}\right) \\
& =\frac{\partial}{\partial Z}\left(U_{B} \sum_{i=1}^{5} C_{i b} C p_{i}\left(T_{b}\right) T_{b}\right)-\frac{1}{A_{R}} \frac{\mathrm{d} A_{B}}{\mathrm{~d} Z} h_{b e}\left(T_{b}-T_{e}\right)+\delta_{b} r_{b 1} \Delta H_{r, 1}
\end{aligned}
$$

- Heat balance for the ith gas:

0 In the emulsion

$$
\begin{aligned}
& \sum_{i=1}^{5} \frac{\partial}{\partial t}\left(\delta_{e} C_{i e} C p_{i}\left(T_{e}\right) T_{e}\right) \\
& =U_{E} \frac{\partial}{\partial Z}\left(\sum_{i=1}^{5} C_{i b} C p_{i}\left(T_{e}\right) T_{e}\right)+\frac{1}{A_{R}} \frac{\mathrm{d} A_{B}}{\mathrm{~d} Z} h_{b e}\left(T_{b}-T_{e}\right) \\
& -\frac{1}{A_{R}} \frac{\mathrm{d} A_{S}}{\mathrm{~d} Z} h_{s e}\left(T_{e}-T_{s}\right)+\delta_{e} r_{e l} \Delta H_{r, 1}+\frac{1}{A_{R}} \frac{\mathrm{d} A_{s}}{\mathrm{~d} Z} \sum_{j=2}^{4} r_{j} \Delta H_{r, j}
\end{aligned}
$$

- Mass equation for the ith gas:

o In the bubbles

$$
\frac{\partial\left(\delta_{b} C_{i b}\right)}{\partial t}=\frac{\partial}{\partial Z}\left(D_{i b} \frac{\partial C_{i b}}{\partial Z}\right)-\frac{\partial\left(\delta_{b} U_{b} C_{i b}\right)}{\partial Z}-\delta_{b} K_{b e}\left(C_{i b}-C_{i e}\right)+\delta_{b} \alpha_{i 1} r_{b 1}
$$


- Mass equation for the ith gas:

0 In the emulsion

$$
\begin{aligned}
\frac{\partial\left(\delta_{e} C_{i e}\right)}{\partial t}= & \frac{\partial}{\partial Z}\left(D_{i e} \frac{\partial C_{i e}}{\partial Z}\right)-U_{e} \frac{\partial\left(\delta_{e} C_{i e}\right)}{\partial Z}+\delta_{e} K_{b e}\left(C_{i b}-C_{i e}\right) \\
& +\delta_{e} \alpha_{i 1} r_{e 1}+\frac{1}{A_{R}} \frac{\mathrm{d} A_{S}}{\mathrm{~d} Z} \sum_{j=2}^{4} \alpha_{i j} r_{j}
\end{aligned}
$$

- Mass equation for the solids:

$$
\frac{\partial M}{\partial t}=-\frac{\partial \dot{m}_{s}}{\partial Z}+\frac{1}{A_{R}} \frac{\mathrm{d} A_{s}}{\mathrm{~d} Z} \sum_{j=2}^{4} \alpha_{i j} r_{j}
$$

The initial and boundary conditions for the equation system $(1-6)$ are:

$$
\begin{gathered}
\text { at } t=0\left\{\begin{array}{l}
C_{i b}=C_{i o} \\
C_{i e}=C_{i o} \\
M=M_{o}
\end{array} \text { at } Z=0 \text { et } t \geq 0\left\{\begin{array}{l}
C_{i b}=C_{i o} \\
C_{i e}=C_{i o}
\end{array}\right.\right. \\
\text { at } Z=H \text { et } t \geq 0\left\{\begin{array}{l}
\frac{\partial C_{i b}}{\partial Z}=0 \\
\frac{\partial C_{i e}}{\partial Z}=0
\end{array}\right. \\
\text { and, at } t=0\left\{\begin{array}{l}
T_{b}=T_{b 0} \\
T_{e}=T_{a m b} \\
T_{s}=T_{a m b}
\end{array} \text { at } Z=0 \text { and } t \geq 0\left\{\begin{array}{l}
T_{b}=T_{b 0} \\
T_{e}=T_{a m b} \\
T_{s}=T_{a m b}
\end{array}\right.\right. \\
\text { at } Z=H \text { and } t \geq 0\left\{\begin{array}{l}
\frac{\partial T_{b}}{\partial Z}=0 \\
\frac{\partial T_{e}}{\partial Z}=0
\end{array}\right.
\end{gathered}
$$

\section{Results}

Three pilot scale gasifiers [12] [38] [39] [40] [41] were simulated in order to see the effect of the H/D ratio and the bed heating dynamics in the gasification kinetics, Table 2 shows their operational parameters.

For each gasifier, different input parameters (gas input superficial velocity, steam input temperature, steam to biomass ratio $\mathrm{S} / \mathrm{C}$ ) are tested. A base was chosen for each variable and it was independently changed around this base, Table 3 shows the conditions simulated.

The steam temperature was limited by the output temperature in the exchange process with the VHTR. In contrast, for higher gas input velocity problems like

Table 2. Operational parameters for the three gasifiers.

\begin{tabular}{cccc}
\hline Gasifier n $^{\circ}$ & Diameter (cm) & Bed height $(\mathrm{m})$ & H/D \\
\hline Gasifier 1 (G1) & 10 & 3.20 & 32.00 \\
Gasifier 2 (G2) & 15 & 1.90 & 12.67 \\
Gasifier 3 (G3) & 22 & 1.10 & 5.00 \\
\hline
\end{tabular}


Table 3. Conditions simulated.

\begin{tabular}{cccc}
\hline Gasifier $^{\circ}$ & Steam Temperatures $(\mathrm{K})$ & $\mathrm{U} / \mathrm{Umf}$ & $\mathrm{S} / \mathrm{C}$ ratio $(\mathrm{mol} / \mathrm{mol})$ \\
\hline $\mathrm{G} 1$ & $1073-1123-1173$ & $2.5-3.5-4.5-5.5-6.5$ & $3.3-2.6-1.3$ \\
$\mathrm{G} 2$ & 1173 & $3.5-4.5-5.5-6.5$ & Minimum \\
G3 & $1073-1123-1173$ & $3.5-4.5-5.5-6.5$ & $3.9-2.2-1.6$ \\
\hline
\end{tabular}

slugging could be present especially for G1, thus the system hydrodynamics would change and create problems in the mass and heat transfer. The system pressure was fixed in $1 \mathrm{~atm}$ and $1 \mathrm{~mm}$ for the particles diameter.

The molar steam to biomass ratio $(\mathrm{S} / \mathrm{C})$ was limited by the minimum biomass input rate in order to maintain the bed height constant; otherwise the system would never achieve the steady state.

The increase in the steam input superficial velocity enhances the turbulence in the system, thus, the heat transfer between the gases and the solids is favored. As a consequence, the solids at the bottom of the reactor are heated faster (Figure 4) and R2 is privileged, hence hydrogen and carbon monoxide yields are increased as seen in Figure 5. The yield of the dry fuel increase with increasing the input gas temperature as found by Kentaro et al. (2010) [42], Lucas et al. (2004) [5], Corella et al. (1991) [41] and Yu et al. (1997) [43].

Given that the only source of heat throughout the reactor is the hot steam, this is the sole source that provides the energy for the endothermic reactions and at the same time to heat the solids; therefore the output gas temperature will be diminished, especially if the rate of $\mathrm{R} 2$ is increased (Figure 5). These trends agree with those found by Velez et al. (2009) [39] and Ross et al. (2007) [44].

The carbon monoxide yield was almost constant for the conditions tested and its concentrations are smaller than those of hydrogen and carbon monoxide. This statement agrees with the results found by Pröll et al. (2008) [7], Z'Graggen and Standifeld (2006) [15] and Kaushal et al. (2008) [8] where the primary product in the steam gasification (or high steam concentrations) is hydrogen and the second is carbon monoxide.

These results are highly dependent of the bed heating dynamics because R1 is exothermic while $\mathrm{R} 2$ is endothermic, thus a higher heating rate throughout the reactor will enhance R2 increasing both the hydrogen and carbon monoxide yields, while a heating rate more gradual will let $\mathrm{R} 1$ to produce more hydrogen and consume the carbon monoxide produced by R1 at the bottom of the gasifier (Figure 6). These results are in good agreement with those found experimentally by Piatkowski et al. (2009) [12].

\section{Conclusions}

A fluidized bed gasifier with nuclear heat for gasifying biomass char (biochar) with steam based on the systems' kinetics is presented as a new method is presented. The reactor modeling is based on the gasification kinetics, mass and energy balances, predicts gas yields and temperature profiles. 


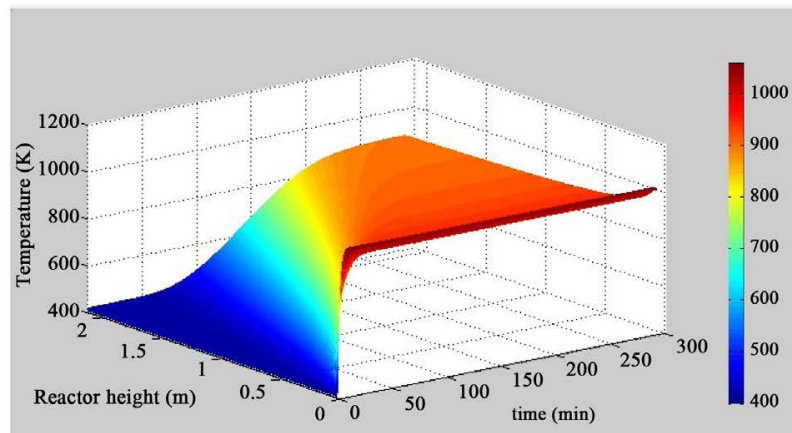

(a)

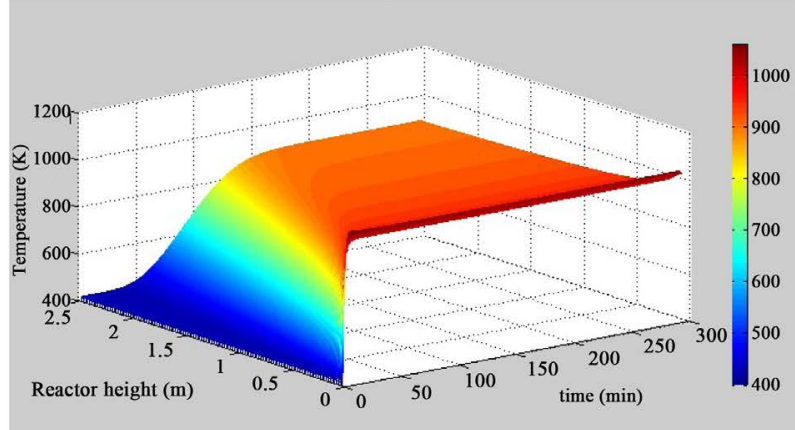

(c)

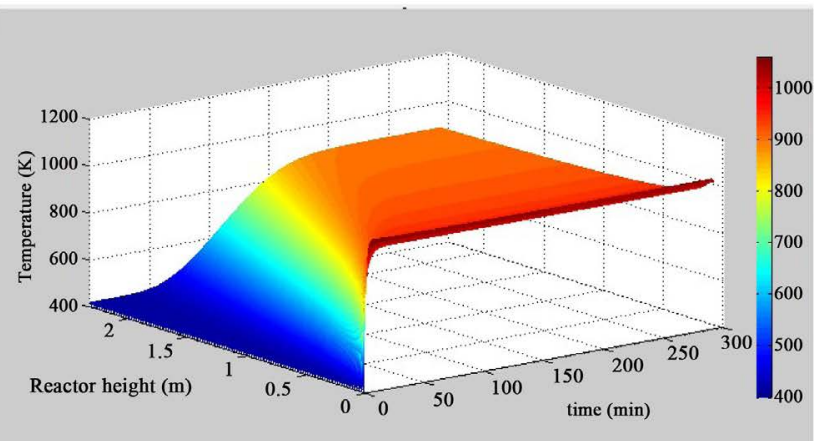

(b)

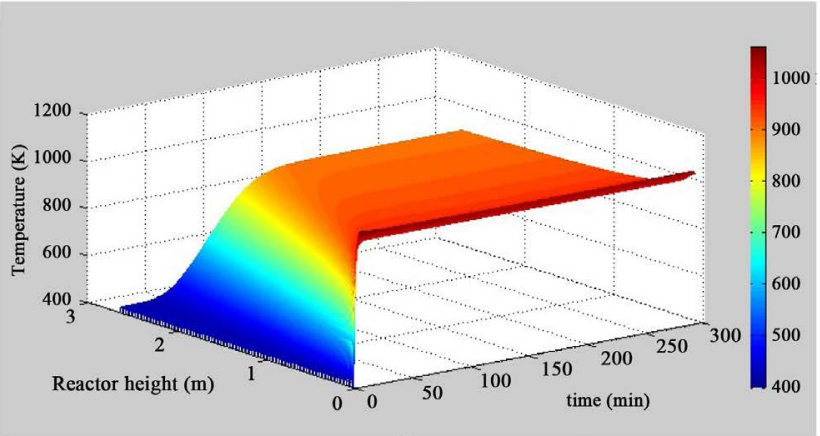

(d)

Figure 4. Solids temperatures dynamics for G2 with: (a) $\frac{U}{U_{m f}}=3.5$; (b) $\frac{U}{U_{m f}}=4.5$; (c) $\frac{U}{U_{m f}}=5.5$; (d) $\frac{U}{U_{m f}}=6.5$.
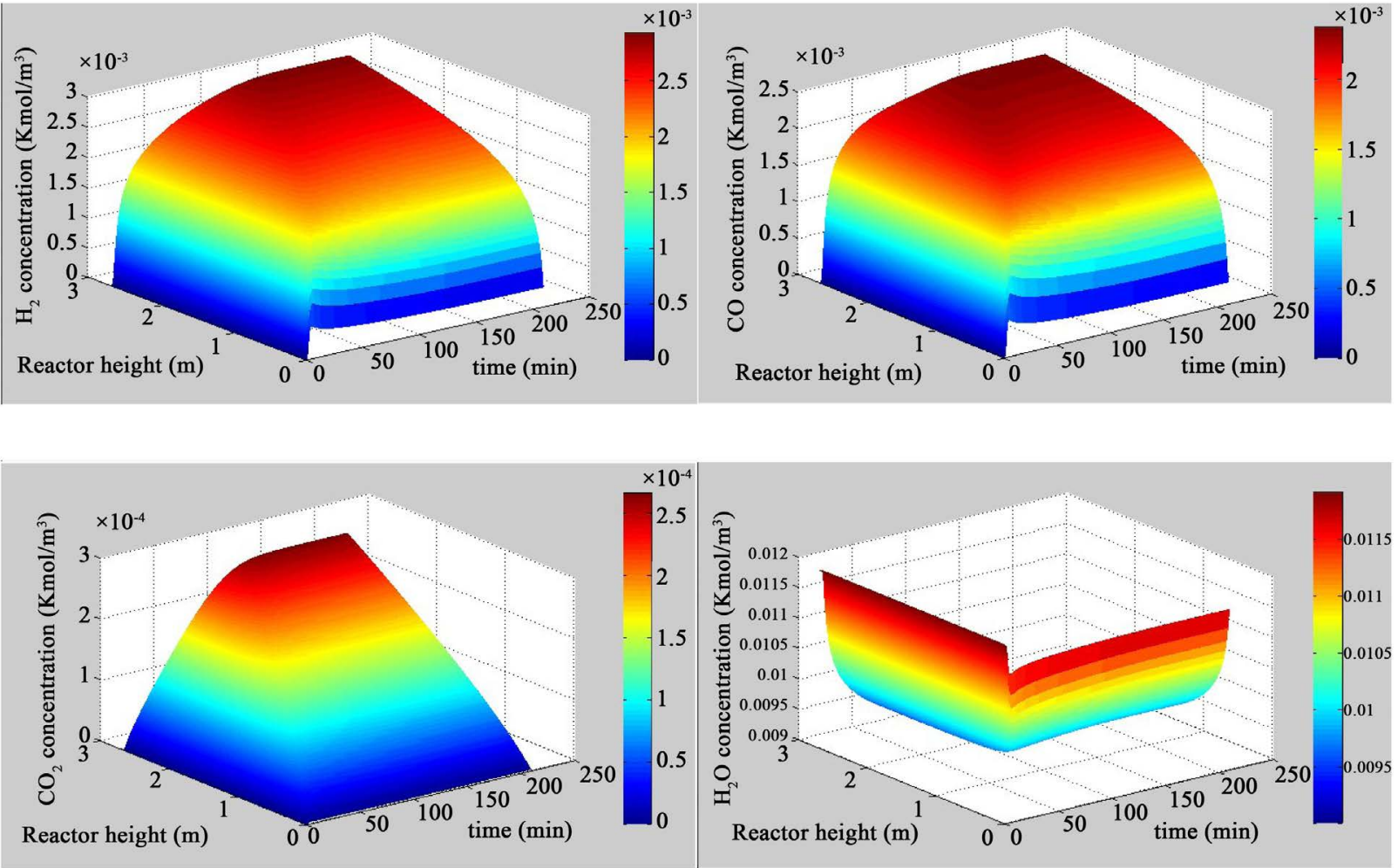

Figure 5. Gas concentrations at their gasifier as a function of time and reactor height, for G2 with $\frac{U}{U_{m f}}=6.5$. 


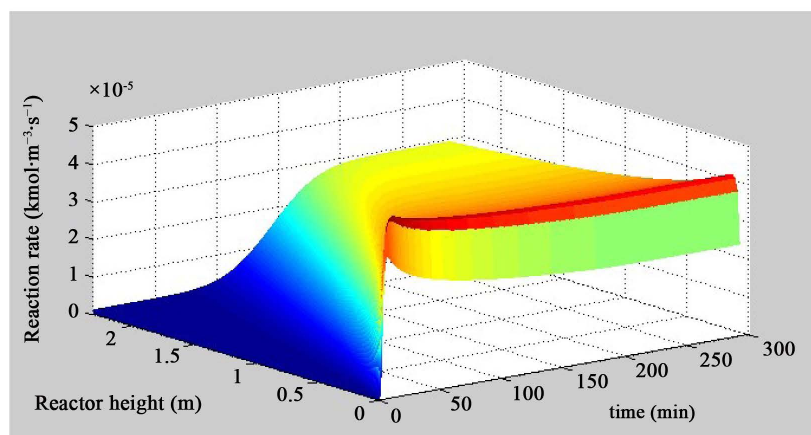

(a)

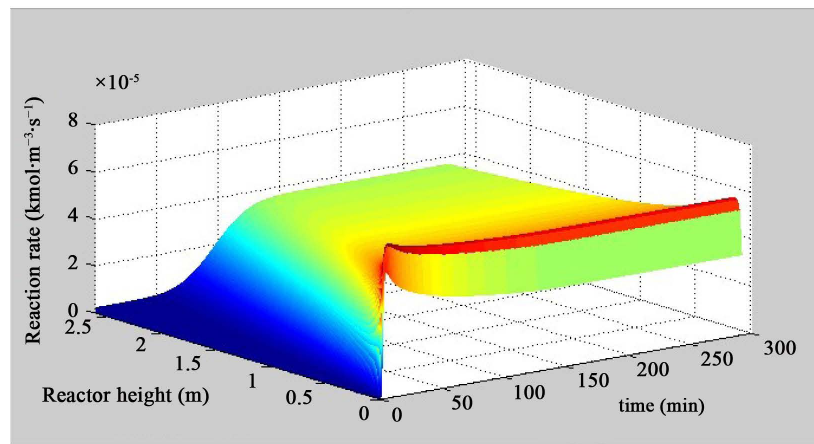

(c)

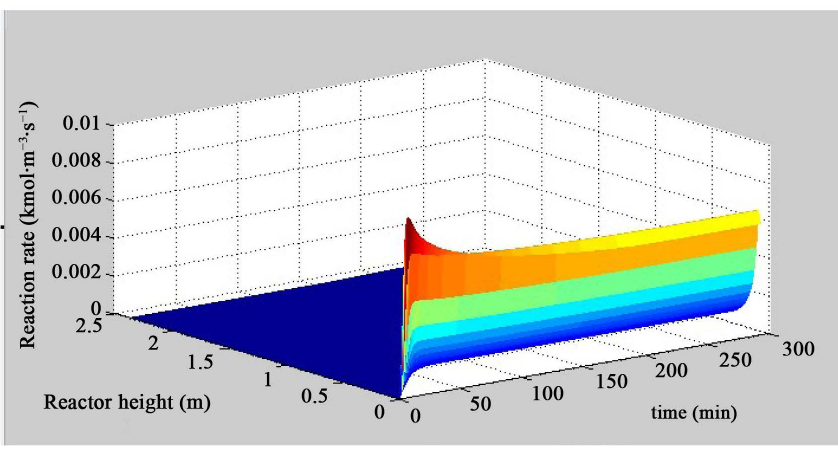

(b)

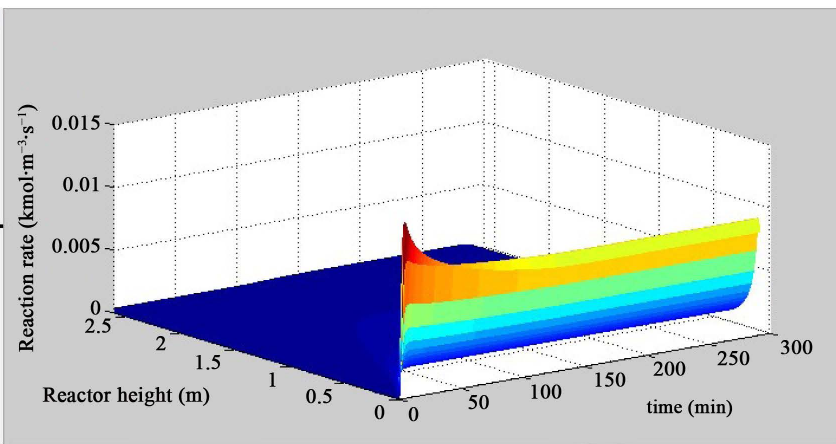

(d)

Figure 6. The reaction rate $\mathrm{R} 1$ and $\mathrm{R} 2$ at their gasifier as a function of time and reactor height: (a) $\mathrm{R} 1, \frac{U}{U_{m f}}=4.5$; (b) R2, $\frac{U}{U_{m f}}=4.5$; (c) R1, $\frac{U}{U_{m f}}=6.5$; (d) R2, $\frac{U}{U_{m f}}=6.5$.

Hydrogen is found to be the principal product of the steam gasification, as reported in the literature data. The carbon dioxide yield seems to be smaller than the ones in other works, but these differences are due principally to the energy source (no combustion is conducted) and that char (no oxygen in the solids) was used as the carbon source.

\section{Conflicts of Interest}

The authors declare no conflicts of interest regarding the publication of this paper.

\section{References}

[1] Lisbona, P. and Romeo, L. (2008) Enhanced Coal Gasification Heated by Unmixed Combustion Integrated with an Hybrid System of SOFC/GT. International Journal of Hydrogen Energy, 33, 5755-5764. https://doi.org/10.1016/j.ijhydene.2008.06.031

[2] Caputo, A., Palumbo, M., Pelagagge, P. and Scacchia, F. (2005) Economics of Biomass Utilization in Combustion and Gasificationplants: Effect of Logistic Variables. Biomass and Bioenergy, 28, 38-51. https://doi.org/10.1016/j.biombioe.2004.04.009

[3] Shen, L., Gao, Y. and Xiao, J. (2008) Simulation of Hydrogen Production from Biomass Gasification in Interconnected Fluidized Beds. Biomass and Bioenergy, 32, 120-127. https://doi.org/10.1016/j.biombioe.2007.08.002 
[4] France, C., Pinto, F., Gulyurltlu, I. and Cabrita, I. (2003) The Study of Reactions Influencing the Biomass Steam Gasification Process. Fuel, 82, 835-842. https://doi.org/10.1016/S0016-2361(02)00313-7

[5] Lucas, C., Szewczyka, D., Blasiaka, W. and Mochidab, S. (2004) High-Temperature Air and Steam Gasification of Densified Biofuels. Biomass and Bioenergy, 27, 563-575. https://doi.org/10.1016/j.biombioe.2003.08.015

[6] Belghit, A., Gordillo, E.D. and El Issami, S. (2009) Coal Steam-Gasification Model in Chemical Regime to Produce Hydrogen in a Gas-Solid Moving Bed Reactor Using Nuclear Heat. International Journal of Hydrogen Energy, 34, 6114-6119. https://doi.org/10.1016/j.ijhydene.2009.05.065

[7] Pröll, T. and Hofbauer, H. (2008) H2 Rich Syngas by Selective $\mathrm{CO}_{2}$ Removal from Biomass Gasification in a Dual Fluidized Bed System Process Modeling Approach. Fuel Processing Technology, 89, 1207-1217. https://doi.org/10.1016/j.fuproc.2008.05.020

[8] Kaushal, P., Pröll, T. and Hofbauer, H. (2008) Model for Biomass Char Combustion in the Riser of a Dual Fluidized Bed Gasification Unit: Part 1-Model Development and Sensitivity Analysis. Fuel Processing Technology, 89, 651-659.

https://doi.org/10.1016/j.fuproc.2007.12.010

[9] Elder, R. and Allen, R. (2009) Nuclear Heat for Hydrogen Production: Coupling a Very High/High Temperature Reactor to a Hydrogen Production Plant. Progress in Nuclear Energy, 51, 500-525. https://doi.org/10.1016/j.pnucene.2008.11.001

[10] Gordillo, E.D. and Belghit, A. (2011) A Two Phase Model of High Temperature Steam-Only Gasification of Biomass Char in Bubbling Fluidized Bed Reactors Using Nuclear. Journal of Hydrogen Energy, 36, 374-381. https://doi.org/10.1016/j.ijhydene.2010.09.088

[11] Gordillo, E.D. and Belghit, A. (2011) A Bubbling Fluidized Bed Solar Reactor Model of Biomass Char High Temperature Steam-Only Gasification. Fuel Processing Technology, 92, 314-321. https://doi.org/10.1016/j.fuproc.2010.09.021

[12] Piatkowski, N., Wieckert, C. and Steinfeld, A. (2009) Experimental Investigation of a Packed-Bed Solar Reactor for the Steam-Gasification of Carbonaceous Feedstocks. Fuel Processing Technology, 90, 360-366. https://doi.org/10.1016/j.fuproc.2008.10.007

[13] Z’Graggen, A. and Steinfeld, A. (2009) Heat and Mass Transfer Analysis of a Suspension of Reacting Particles Subjected to Concentrated Solar Radiation-Application to the Steam-Gasification of Carbonaceous Materials. International Journal of Heat and Mass Transfer, 52, 385-395. https://doi.org/10.1016/j.ijheatmasstransfer.2008.05.023

[14] Melchior, T., Perkins, C., Lichty, P., Weimer, A.W. and Steinfeld, A. (2009) Solar-Driven Biochar Gasification in a Particle-Flow Reactor. Chemical Engineering and Processing, 48, 1279-1287. https://doi.org/10.1016/j.cep.2009.05.006

[15] Z’Graggen, A. and Steinfeld, A. (2008) A Two-Phase Reactor Model for Steam Gasification of Carbonaceous Materials under Concentrated Thermal Radiation. Chemical Engineering and Processing, 47, 655-662.

https://doi.org/10.1016/j.cep.2006.12.003

[16] Trommer, D., Noembrini, F., Fasciana, M., Rodriguez, D., Morales, A., Romero, M. and Steinfeld, A. (2005) Hydrogen Production by Steam-Gasification of Petroleum Coke Using Concentrated Solar Power. International Journal of Hydrogen Energy, 30, 605-618. https://doi.org/10.1016/j.ijhydene.2004.06.002

[17] Zedtwitz, P., Lipinski, W. and Steinfeld, A. (2007) Numerical and Experimental 
Study of Gas-Particle Radiative Heat Exchange in a Fluidized-Bed Reactor for Steam-Gasification of Coal. Chemical Engineering Science, 62, 599-607. https://doi.org/10.1016/j.ces.2006.09.027

[18] Muller, R., Zedtwitz, P., Wokaun, A. and Steinfeld, A. (2003) Kinetic Investigation on Steam Gasification of Charcoal under Direct High-Flux Irradiation. Chemical Engineering Science, 58, 5111-5119. https://doi.org/10.1016/j.ces.2003.08.018

[19] Aigner, I., Pfeifer, C. and Hofbauer, H. (2011) Co-Gasification of Coal and Wood in a Dual Fluidized Bed Gasifier. Fuel, 90, 2404-2412. https://doi.org/10.1016/j.fuel.2011.03.024

[20] Kim, J.-W., Mun, T.-Y., Kim, J.-O. and Kim, J.-S. (2011) Air Gasification of Mixed Plastic Wastes Using a Two-Stage Gasifier for the Production of Producer Gas with Low Tar and a High Caloric Value. Fuel, 90, 2266-2272. https://doi.org/10.1016/j.fuel.2011.02.021

[21] Xue, Q., Heindel, T.J. and Fox, R.O. (2011) A CFD Model for Biomass Fast Pyrolysis in Fluidized-Bed Reactors. Chemical Engineering Science, 66, 2440-2452. https://doi.org/10.1016/j.ces.2011.03.010

[22] Michel, R., Rapagnà, S., Di Marcello, M., Burg, P., Matt, M., Courson, C. and Gruber, R. (2011) Catalytic Steam Gasification of Miscanthus X Giganteus in Fluidised Bed Reactor on Olivine Based Catalysts. Fuel Processing Technology, 92, 1169-1177. https://doi.org/10.1016/j.fuproc.2010.12.005

[23] Xu, Q.X., Pang, S.S. and Levi, T. (2011) Reaction Kinetics and Producer Gas Compositions of Steam Gasification of Coal and Biomass Blend Chars. Chemical Engineering Science, 66, 2141-2148. https://doi.org/10.1016/j.ces.2011.02.026

[24] Chen, T.J., Wu, C., Liu, R.H., Fei, W.T. and Liu, S.Y. (2011) Effect of Hot Vapor Filtration on the Characterization of Bio-Oil from Rice Husks with Fast Pyrolysis in a Fluidized-Bed Reactor. Bioresource Technology, 102, 6178-6185. https://doi.org/10.1016/j.biortech.2011.02.023

[25] Yu, J., Yao, C.B., Zeng, X., Geng, S., Dong, L., Wang, Y., Gao, S.Q. and Xu, G.W. (2011) Biomass Pyrolysis in a Micro-Fluidized Bed Reactor: Characterization and Kinetics. Chemical Engineering Journal, 168, 839-847. https://doi.org/10.1016/j.cej.2011.01.097

[26] Göransson, K., Söderlind, U. and Zhang, W. (2011) Experimental Test on a Novel Dual Fluidised Bed Biomass Gasifier for Synthetic Fuel Production. Fuel, 90, 1340-1349. https://doi.org/10.1016/j.fuel.2010.12.035

[27] Chen, S.Y., Wang, D., Xue, Z.P., Sun, X.Y. and Xiang, W.G. (2011) Calcium Looping Gasification for High-Concentration Hydrogen Production with $\mathrm{CO}_{2}$ Capture in a Novel Compact Fluidized Bed: Simulation and Operation Requirements. International Journal of Hydrogen Energy, 36, 4887-4899.

https://doi.org/10.1016/j.ijhydene.2010.12.130

[28] Detournay, M., Hemati, M. and Andreux, R. (2011) Biomass Steam Gasification in Fluidized Bed of Inert or Catalytic Particles: Comparison between Experimental Results and Thermodynamic Equilibrium Predictions. Powder Technology, 208, 558-567. https://doi.org/10.1016/j.powtec.2010.08.059

[29] Loha, C., Chatterjee, P.K. and Chattopadhyay, H. (2011) Performance of Fluidized Bed Steam Gasification of Biomass-Modeling and Experiment. Energy Conversion and Management, 52, 1583-1588. https://doi.org/10.1016/j.enconman.2010.11.003

[30] de Andrés, J.M., Narros, A. and Rodríguez, M.E. (2011) Air-Steam Gasification of Sewage Sludge in a Bubbling Bed Reactor: Effect of Alumina as a Primary Catalyst. Fuel Processing Technology, 92, 433-440. 
https://doi.org/10.1016/j.fuproc.2010.10.006

[31] Kaewluan, S. and Pipatmanomai, S. (2011) Gasification of High Moisture Rubber Woodchip with Rubber Waste in a Bubbling Fluidized Bed. Fuel Processing Technology, 92, 671-677. https://doi.org/10.1016/j.fuproc.2010.11.026

[32] Mohammed, M.A.A., Salmiaton, A., Wan Azlina, W.A.K.G., Mohammad Amran, M.S. and Fakhru'l-Razi, A. (2011) Air Gasification of Empty Fruit Bunch for Hydrogen-Rich Gas Production in a Fluidized-Bed Reactor. Energy Conversion and Management, 52, 1555-1561. https://doi.org/10.1016/j.enconman.2010.10.023

[33] Piatkowski, N., Wieckert, C. and Steinfeld, A. (2008) Solar-Driven Coal Gasification in a Thermally Irradiated Packed-Bed Reactor. Energy and Fuels, 22, 2043-2052. https://doi.org/10.1021/ef800027c

[34] Gomez-Barea, A. and Leckner, B. (2010) Modeling of Biomass Gasification in Fluidized Bed. Progress in Energy and Combustion Science, 36, 444-509. https://doi.org/10.1016/j.pecs.2009.12.002

[35] Sadaka, S.S., Ghaly, A.E. and Sabbah, M.A. (2002) Two Phase Biomass Air-Steam Gasification Model for Fluidized Bed Reactors: Part I Model Development. Biomass \& Bioenergy, 22, 439-462. https://doi.org/10.1016/S0961-9534(02)00023-5

[36] Kunii, D. and Levenspiel, O. (1968) Bubbling Bed Model. Industrial \& Engineering Chemistry Fundamentals, 7, 446-452. https://doi.org/10.1021/i160027a016

[37] Rosseland, S. (1936) Theoretical Astrophysics. Oxford University Press, Clarendon.

[38] Kunii, D. and Levenspiel, O. (1991) Fluidization Engineering (Series in Chemical Engineering). Second Edition, Butterworth-Heinemann, Stoneham.

[39] Velez, J.F., Chejne, F., Valdes, C.F., Emery, E.J. and Londoño, C.A. (2009) Co-Gasification of Colombian Coal and Biomass in Fluidized Bed: An Experimental Study. Fuel, 88, 424-430. https://doi.org/10.1016/j.fuel.2008.10.018

[40] Encinar, J.M., Gonzalez, J.F. and Gonzalez, J. (2002) Steam Gasification of Cyanara cardunculus L.: Influence of Variables. Fuel Processing Technology, 75, 27-43. https://doi.org/10.1016/S0378-3820(01)00247-8

[41] Corella, J., Aznar, M.P., Delgado, J. and Aldea, E. (1991) Steam Gasification of Cellulosic Wastes in a Fluidized Bed with Downstream Vessels. Industrial and Engineering Chemistry Research, 30, 2252-2262. https://doi.org/10.1021/ie00058a003

[42] Kentaro, U., Kouichi, Y., Tomoaki, N. and Kunio, Y. (2010) High Temperature Steam-Only Gasification of Woody Biomass. Applied Energy, 87, 791-798. https://doi.org/10.1016/j.apenergy.2009.09.035

[43] Yu, Q., Brage, C., Chen, G. and Sjostrom, K. (1997) Temperature Impact on the Formation of Tar from Biomass Pyrolysis in a Freefall Reactor. Journal of Analytical and Applied Pyrolysis, 40, 481-489. https://doi.org/10.1016/S0165-2370(97)00017-X

[44] Ross, D., Noda, R., Horio, M., Kosminski, A., Ashman, P. and Mullinger, P. (2007) Axial Gas Profiles in a Bubbling Fluidised Bed Biomass Gasifier. Fuel, 86, 1417-1429. https://doi.org/10.1016/j.fuel.2006.11.028 


\section{Nomenclature}

$A_{B}$ : Bubble phase area in the cross sectional area $\left(\mathrm{m}^{2}\right)$

$A_{R}:$ Bed cross sectional area $\left(\mathrm{m}^{2}\right)$

$A r$ : Archimedes number

$A_{S}$ : Solid phase area in the cross sectional area $\left(\mathrm{m}^{2}\right)$

$C_{i b}$ : Concentration ith gas in the bubble phase $\left(\mathrm{kg} \cdot \mathrm{m}^{-3}\right)$

$C_{i e}$ : Concentration ith gas in the emulsion phase $\left(\mathrm{kg} \cdot \mathrm{m}^{-3}\right)$

$C_{g}$ : Total gas concentration $\left(\mathrm{kg} \cdot \mathrm{m}^{-3}\right)$

$C_{i}^{\prime}$ : Current value of concentration in the iteration $\left(\mathrm{kg} \cdot \mathrm{m}^{-3}\right)$

$C p_{e p}$ : Specific heat of the emitter plate $\left(\mathrm{kJ} \cdot \mathrm{kg}^{-1} \cdot \mathrm{K}^{-1}\right)$

$C p_{i}$ : Specific heat of $i$ th gas $\left(\mathrm{kJ} \cdot \mathrm{kg}^{-1} \cdot \mathrm{K}^{-1}\right)$

$D$ : Bed diameter $(\mathrm{cm})$

$d_{b}:$ Bubble diameter $(\mathrm{m})$

$D_{i b}$ : Diffusion of the $i$ th gas in the bubble phase $\left(\mathrm{m}^{2} \cdot \mathrm{s}^{-1}\right)$

$D_{i e}$ : Diffusion of the $i$ th in the emulsion phase $\left(\mathrm{m}^{2} \cdot \mathrm{s}^{-1}\right)$

$d_{p}:$ Particle diameter $(\mathrm{m})$

g. Acceleration of gravity $\left(\mathrm{m} \cdot \mathrm{s}^{-2}\right)$

$\Delta G_{i}^{o}$ : Free energy of formation of compound $i\left(\mathrm{~kJ}^{\mathrm{k}} \cdot \mathrm{kg}^{-1}\right)$

$H$ : Bed height $(\mathrm{m})$

$h_{b e}$ : Convection heat coefficient between bubbles and emulsion gas $\left(\mathrm{k} \cdot \mathrm{s}^{-1} \cdot \mathrm{m}^{-2} \cdot \mathrm{K}^{-1}\right)$

$h_{s e}$ : Convection heat coefficient between solids and emulsion gas $\left(\mathrm{kJ} \cdot \mathrm{s}^{-1} \cdot \mathrm{m}^{-2} \cdot \mathrm{K}^{-1}\right)$

$\Delta H_{r, j}$ : Enthalpy of the jth reaction $\left(\mathrm{kJ} \cdot \mathrm{kg}^{-1}\right)$

$K$ : Extinction coefficient $\left(\mathrm{m}^{-1}\right)$

$K_{e b}$ : Mass transfer coefficient between emulsion gas and bubbles $\left(\mathrm{s}^{-1}\right)$

$k_{g}$ : Mass transfer coefficient between emulsion gas and solids $\left(\mathrm{s}^{-1}\right)$

$M$ : Total solid mass in the reactor $(\mathrm{kg})$

$M_{e p}:$ Emitter plate mass $(\mathrm{kg})$

$\dot{m}$ : Biochar mass flow rate $\left(\mathrm{kg} \cdot \mathrm{s}^{-1}\right)$

$\dot{m}_{e}$ : Biochar mass input flow rate $\left(\mathrm{kg} \cdot \mathrm{s}^{-1}\right)$

$\dot{m}_{s}$ : Biochar mass output flow rate $\left(\mathrm{kg} \cdot \mathrm{s}^{-1}\right)$

$Q_{r}$ : Radiative flux density in the bed $\left(\mathrm{W} \cdot \mathrm{m}^{-2}\right)$

$Q_{r \text { solar }}$ : Concentrated thermal radiation $\left(\mathrm{W} \cdot \mathrm{m}^{-2}\right)$

$R$ : Universal gas constant $\left(\mathrm{kJ} \cdot \mathrm{mol}^{-1} \cdot \mathrm{K}^{-1}\right)$

$r_{i b}$ : Rate of the $i$ th reaction in the bubbles $\left(\mathrm{kg} \cdot \mathrm{m}^{-3} \cdot \mathrm{s}^{-1}\right)$

$r_{i e}$ : Rate of the ith reaction in the emulsion gas $\left(\mathrm{kg} \cdot \mathrm{m}^{-3} \cdot \mathrm{s}^{-1}\right)$

$r_{s}$ : Rate of the $i$ th reaction in the solids $\left(\mathrm{kg} \cdot \mathrm{m}^{-3} \cdot \mathrm{s}^{-1}\right)$

$t$. Time (s)

$T_{b}$ : Bubbles temperature $(\mathrm{K})$

$T_{e}$ : Emulsion gas temperature (K)

$T_{e p}$ : Emitter plate temperature $(\mathrm{K})$

$T_{s}$ : Solids temperature $(\mathrm{K})$

$T_{o}$ : Input steam temperature $(\mathrm{K})$

$U$ : Gas input superficial velocity $\left(\mathrm{m} \cdot \mathrm{s}^{-1}\right)$ 
$U_{B}$ : Bubble rising velocity $\left(\mathrm{m} \cdot \mathrm{s}^{-1}\right)$

$U_{E}:$ Emulsion velocity $\left(\mathrm{m} \cdot \mathrm{s}^{-1}\right)$

$U_{m f}$ : Minimum fluidization velocity $\left(\mathrm{m} \cdot \mathrm{s}^{-1}\right)$

$Z$ : Axial direction inside the reactor $(\mathrm{m})$

Greek symbols

$\delta_{b}$ : Volume fraction of bubbles $\left(\mathrm{m}^{3}\right.$ bubbles $\mathrm{m}^{3}$ reactor)

$\delta_{e}$ : Volume fraction of emulsion gas $\left(\mathrm{m}^{3}\right.$ emulsion gas $/ \mathrm{m}^{3}$ reactor)

$\delta_{s}$ : Volume fraction of solids $\left(\mathrm{m}^{3}\right.$ solids $/ \mathrm{m}^{3}$ reactor)

$\varepsilon_{m f}:$ Bed voidage at minimum fluidization conditions

$\epsilon$ : Solids emissivity

$\rho_{g}:$ Gas density $\left(\mathrm{kg} \cdot \mathrm{m}^{-3}\right)$

$\rho_{s}:$ Solid density $\left(\mathrm{kg} \cdot \mathrm{m}^{-3}\right)$

$\sigma:$ Stefan-Boltzmann constant $\left(\mathrm{W} \cdot \mathrm{m}^{-2} \cdot \mathrm{K}^{-4}\right)$

$\mu_{g}:$ Gas viscosity (Pa.s) 